\section{Te Ropu Rangahau Tikanga Rua: The Establishment of a Bicultural Research Group, under the Control of Maori People for the Benefit of Maori People $^{1}$}

\author{
RUSSELL BISHOP
}

erious concerns about research involving Maori people have been raised by Walker (1979), Curtis (1983), Stokes (1985, 1987), Smith (1991) and Bishop and Glynn (1992). These authors caution that research into Maori people and issues associated with Maoridom should not perpetuate the monocultural research methodology and findings so common in the literature.

One of their major concerns is that much research has concentrated on identifying characteristics that cause sub-cultural group members to function unsuccessfully in the common culture. Also, a great deal of research in to Maori people's affairs has had belittling or disadvantaging effects. Much of the research has been designed to answer research questions that have benefited the researchers and the non-Maori academic community rather than the Maori people themselves. Many research activities by non-Maori have disadvantaged and even belittled the mana of Maori knowledge and understanding of their own history.

Maori people have become increasingly concerned about the capture of their past by others, and the manipulation of this knowledge both to enhance the life chances of others and to belittle the life chances of Maori people. Fundamental to this concern is the question of who has control of the knowledge? Whose purpose does research fulfill?

Maori people resent being dissected with the same model as used by natural scientists. In this model all natural things can be seen as elements, as objects of study from some neutral stance outside of the people themselves. This neutral stance is being seriously questioned by Kaumatua and Maori people in general. This neutrality is now seen as another myth, created by those in positions of authority to perpetuate their own interests.

The compartmentalisation that is part of the application of the dissection model to the lives of Maori people has involved reification or the removal of elements from their sense-making context. This has not only had belittling effects but has also helped to destroy historical memory. Giroux and Friere in Livingstone (1987) submit that:

\begin{abstract}
... forgetting instances of human suffering and the dynamics of human struggle not only rendered existing forms of domination natural and acceptable but also made it more difficult for those who were victimised by such oppression to develop an ontological basis for challenging the ideological and political conditions that produced such suffering (p. xv).
\end{abstract}

There is now developing an ontological basis for challenging the dominance. It has been characterised by Maori groups refusing to be part of research projects unless the kaupapa has been Maori initiated and controlled and has seen the rise of a Maori controlled interactive research. Bishop and Glynn (1992) after (Giroux 1983, and Carr \& Kemmis, 1986) suggest that irrespective of particular research strategies, researchers who are committed to a Maori kaupapa need to see their role as empowering. This can be supported by establishing systems of power-sharing within the research process.

\section{Establishing a Research Group}

The nature of the paradigm within which educational research is conducted into Maori peoples' and children's lives needs re-evaluation in light of the above concerns. As an initial step in this direction it was decided to formally establish a research group, entitled Te Ropu Rangahau Tikanga Rua within the Education Department of the University of Otago. The kaupapa was to be one of empowering research, where research conducted into Maori issues would be for the betterment of Maori people, under the control of Maori people.

The kaupapa of Te Ropu Rangahau was presented to the Otago Maori Council (OMC), (Bishop 1992b) via its associate committee, 
META, the Maori Education and Training Association, in order that local Mana Whenua runanga and Mata Waka ropu could consider the idea. Initial approval for the idea has been given. Currently negotiations are underway for the appointment of a Kaumatua and a wider communitybased support and monitoring group.

The need for a bicultural research group within the Education Department of the University of Otago was also introduced to educational researchers at the 13th NZARE conference in Dunedin in November of 1991 (Bishop, 1991a), to an international workshop on inter-cultural communication at the East-West Centre in Hawaii during July of 1992 (Bishop, 1992a) and the results of the projects undertaken in 1992 were presented at the joint AARE/NZARE conference at Geelong, Australia, in November, 1992.

\section{Empowerment as a Research Kaupapa}

In a major report commissioned by the Ministry of Education, Hirsch (1990) identified a number of important issues and recommended a number of changes necessary within mainstream educational institutions to improve the achievement of Maori students in order to "promote social justice and racial harmony" (p. 9). Central to the large number of issues that emerged during the study was the central theme of empowerment of Maori people, a "shedding of the cloak of dependency" (p. 29).

\section{Hirsch noted that:}

empowerment of Maori people is really the issue underlying all the others - bilingual education, the quality of teachers, the nature of schools, curriculum and resource development, the assessment of students and parent education (p. 9).

Empowerment means Maori people having more real say in decision making at the school level and at the planning level, in designing curriculum and resources, in managing research, so that what is being done is not for Maori by Pakeha but by Maori for themselves.

However, while it is this process of empowerment of Maori people that will enhance the achievement of Maori students in mainstream educational institutions, a process that will result in the transformation of these institutions, it is essential that it is done with the support of the individuals who currently work there. Indeed this notion of empowerment is supported by Walker's (1990) statement that: the Maori as a minority of $12 \%$ of the population of three million, cannot achieve justice or resolve their grievances without Pakeha support. For this reason, Pakeha are as much a part of the process of social transformation in the post-colonial era as radical and activist Maori (p. 234)

The pursuit of social justice is a task that all New Zealanders must be engaged upon. There is a growing temptation to leave solutions to the problems of inequitable educational outcomes to Maori people themselves now that Maori educational initiatives are gaining ground. This is to ignore the reality of the post colonial reconstruction. To remove a people's resource base over a period of a century and a half, to deny them access to the skills necessary in the modern industrial society in which we all now live, and then to expect them to solve problems which have become systemic is simply further injustice, not empowerment. Empowerment means decision making from a position of strength and wealth, not from a position of being cast adrift, to fend for oneself.

\section{Sites for Research}

Hirsch (1990) stated that most of the Maori educationalists he spoke to agreed that separate Kaupapa Maori institutions offered Maori the best chance of equitable outcomes (p. 7). However, he stressed that the site of the greatest challenge still is in mainstream schools for "almost everyone recognised that well over $90 \%$ of Maori pupils will remain in regular state schools for many years to come" (pp. 7-8). As Walker (1979) stated over a decade ago:

It is an axiom of Social Science that social phenomena have multiple causes, and if these causes are to be found the whole field needs to

be examined, in other words it is time that researchers examined Pakeha society itself (p. 91).

The need to critically evaluate the contribution mainstream schools can make to the educational achievement of Maori pupils is well summarised by the Waitangi Tribunal (1986, in Hirsch 1990, p. 24) when they conclude that: 
the education system in New Zealand is operating unsuccessfully because too many Maori children are not reaching an acceptable level of education. For some reason they do not or cannot take full advantage of it. Their language is not protected and their scholastic achievements fall far short of what they should be. The promises of the Treaty of Waitangi of equality of education as in all other human rights are undeniable. Judged by the system 's own standards Maori children are not being successfully taught, and for that reason alone, quite apart from the duty to protect the Maori language, the education system is being operated in breach of the Treaty. (In Hirsch, 1990, p. 24)

It is perhaps necessary at this point to identify three categories of educational research and development in order to address the issues of power and control over research. The first is Maori controlled institutions, Kohanga Reo, Kura Kaupapa Maori and Waananga Maori in which research is without doubt within the control of the whanau, by Maori for Maori. There are no problems controlling who does research or in choosing appropriate models of instruction and development. However, the second category is educational research into the needs of Maori pupils within mainstream schools, and this is the crisis location. It is here where Maori must gain control and where culturally preferred methods need to be implemented. It is here that the needs of Maori students particularly with regard to life style enhancement and life chance development must be addressed. It is here that educational researchers are challenged to critique their methodological framework and to assess the purpose of their work. Smith (1990) claims that mainstream schools do not address this category for they concentrate on the third category, which is educational research for non-Maori pupils within mainstream institutions. It is suggested that this categorisation of locations is a useful device to enable educational researchers to clarify the direction of their goals and objectives and to acknowledge that there are areas that are restricted.

\section{Control over Research}

The dominance of Pakeha research kaupapa needs to be questioned in order to increase Maori control over the research process. To achieve this shift in control, initially there is the need for an increase in the number of Maori researchers. Ohia (1979) states that:
Research which will present the Maori people with the advantages needed to address the inequalities needs to be led by Maori people. This does not stop anyone else from taking part. However it does signal the fact that Maori people are the appropriate people to establish research programmes which are needed to assist Maori people to attain their true status in this country (p. 9).

In this vein, Hirsch (1990) quotes one leader in Maori education as saying "I don't mind who studies a topic like this providing it leads to changes for the betterment of our people" (p. 5). Which is not quite what Ohia meant and could lead to very liberal interpretations.

Hirsch and the Ministry may need reminding that there are a significant number of Maori educators who do not agree with this idea, and who would say that Maori research needs to be done by Maori people only. The limitation by National Trust of Kohanga Reo on who can conduct research in Kohanga is in this category. Therefore researchers need to be cognisant of the wishes of these groups and approach their research with this in mind. Where Maori people are happy for non-Maori to conduct research, this author suggests that the kaupapa needs to be empowering research, in that research needs to be conducted for the betterment of Maori people, but within the kaupapa of Maori control.

As a response to this imperative, the bicultural research group within Otago's Education Department, while being orientated toward the primary function of the University, namely research, acts within the kaupapa of empowering research. Members of such a group act as facilitators of educational research to aid the enhancement of the life styles and the improvement of life chances for Maori children and people in general.

\section{Considerations}

For research to be empowering the process of research needs to be collaborative (Bishop and Glynn, 1992). It is essential that this collaboration and cooperation be instigated prior to the commencement of the research. It is too late once the research project has commenced to question the objectives, and questioning of objectives later on can be a very painful process. Smith (1991) suggests a series of questions that need to be answered at the commencement of any project. 
These questions need elaboration in Otago-Southland to acknowledge the potential dual conflict that exists in this region relating to Maori issues. There appears to be here in the South a ready willingness to come to terms with the need for bicultural initiatives and imperatives, but because there is a limited range of bicultural "conscientising" experiences available to people in powerful decision making positions, there is a limited degree of comprehension about the mechanisms necessary to narrow the gap between the agreed necessity for bicultural initiatives (the theory) and the actual changes needed to promote change and cater for ethnic diversity (the practice).

Following consideration of the concerns about research, clarification of the site for research, issues of power and control of research need to be addressed. The following questions and imperatives need to be considered at the commencement of an educational research project.

1. Who is going to initiate the research? and why? What are the goals of the project? Who sets the goals? Who will it benefit? Is the research for the betterment of Maori people? If so, in what way? It is very important to be specific here. The questions of initiation, goal setting and benefits are crucial and need to be answered honestly. Answers like "It will raise their self esteem" are to be treated with extreme suspicion for they are open to the widest interpretation. Specific, measurable, participant driven goals must be set. If Maori people/students are not involved at this initial stage then there can be no valid answer to these questions and the research should not proceed. The aim is to develop a working research community.

2. Who is going to design the work? This raises questions about power relationships within the research community; is there a hierarchy where only token representation is introduced or are Maori people directly involved with the outcome of the research? Also issues of mana whenua and mata waka status need consideration. The research community must be a community of interest.

3. Who is going to do the work? Have the participants been organised hierarchically? Is there someone who gets to do work that they have not really been part of designing and of which they are not really going to be able to share in the rewards? Researchers must be research participants and participants must be researchers. If any of the participant research group do not have the skills necessary to cooperate, then this points to the need for participants to acquire those skills that may be of use to the community of interest. An example in the context of research into learning and teaching is that the researchers, as part of their bicultural competence and experiences, may need to take lessons, prepare resources, help with control and discipline and clean up messes. Cross cultural competency is necessary as well as the appropriate pedagogic skills. If the researchers do not satisfy these requirements then they will impose an additional burden on the research community and will meet resistance. This again raises the question of what are the power relationships between all participants in a research project? Hierarchical? cooperative? empowering? How are decisions made? If a teacher is involved, is the teacher a coworker/researcher? Does he/she feel part of the project? Is there a clear boss who directs operations, or is there a community of equality? This must be a community sharing the load.

4. What rewards will there be? Who gets the rewards? Who gets their name on any publications? What assessment and evaluation procedures will be used to establish rewards? Who decides on the assessment and evaluation? This must be a community where rewards are shared.

5. Who is going to have access to the research findings? This is one area in which Maori and Pakeha views may differ enormously, and present a weighty challenge to researchers. Ethical considerations affecting both cultures need to be considered at the commencement of the project. Will the findings be available to the wider educational community in a form that is readily understandable? Will the findings presented in a culturally appropriate manner within one culture, be acceptable to the other? This raises the need for a research community dedicated to communication for betterment. 
6. Who is the researcher accountable to? Maori insistence that only Maori do Maori research is based upon the reality that only Maori people are truly accountable to their own people. Accountability, moreover, operates at several levels; iwi members to iwi, hapu members to hapu, whanau members to whanau. Non-Maori are just not as accountable to Maori people and can never be so. This is anathema to the western tradition which holds the belief that a researcher has an inalienable right to knowledge and truth. Smith (1991) emphasises that nonMaori have often misconstrued information about Maori society so badly as to have caused harm. These misconstructions have been ideologically generated (Simon, 1990; Belich 1987; Walker, 1990) so that critical analysis is essential. Therefore if non-Maori are to be involved in Maori research, and I believe they should be, there must be the development of a community of researchers where the locus of accountability is clearly acknowledged before research is undertaken.

7. Who has the control over the distribution of knowledge, including the modes of distribution? Some Maori groups are happy to interact with non-Maori researchers and practising teachers, for example in the development of bicultural curricula.

However, there needs to be clear understanding of the cultural value of certain knowledge and of the culturally preferred means of passing on such ideas (King 1976). This issue is also one of accountability and is inexorably tied to the issue of power over knowledge. Young (1971 in Jones et al., 1990) recognised the political power that control of knowledge can be turned into:

The control over what counts as knowledge and the control over the institutions where such knowledge is practised, allows for dominant interest groups to perpetuate and maintain their positions of dominance and advantage. (p. 151).

The control exercised by the dominant Pakeha research community needs to be challenged in order that the power of research can be unleashed for the betterment of Maori people. It has been clearly shown that in New Zealand the political, social and economic domination of Maori by Pakeha society has been, and continues to be, facilitated by the schooling and education system serving the needs of the dominant society (Simon, 1990; Smith, 1990; Jones et al., 1990). Bicultural research initiatives may offer a means to counter this process. Therefore there needs to be developed a research community where the ownership of knowledge is acknowledged and guarded.

\section{Current Research of Te Ropu Rangahau Tikanga Rua}

Research, design and assessment procedures are guided by the kaupapa of the research group. Future post-graduate studies within a bi-cultural M.Ed. degree will also be based on this kaupapa. Projects already underway within the kaupapa of te Ropu Rangahau Tikanga Rua include:

1. He Whakawhanaungatanga Tikanga Rua (Bishop, 1991b). A posopographic (multiple life history) study of a family diaspora ${ }^{2}$ created by the impact of conflicting hegemonies during the crucial decades $^{3}$ of New Zealand's history. The initial results of this project were reported to the 13th NZARE conference in 1991 (Bishop 1991c) and returned to the family members who participated in the research.

2. An evaluation of the Hui Rangatahi weekend held for senior school and post-school rangatahi Maori. This hui was initiated in Dunedin by the local Runanga, and tertiary institutions were able to display what they had to offer Maori students. The research involved investigation of the various expectations of the organisers, parents and schools, collation of an evaluation questionnaire and interviews with participants six months on. This report was a contract consultancy and presented to the sponsors earlier in the year (Bishop, Bradley and Tokona, 1992a).

3. The investigation of Tatari, Tautoko, Tauawhi, reading tutoring procedures within Maori kaupapa contexts. The production of a training video is now completed and the process of collaboration and participation was reported to the joint AARE/NZARE conference in Melbourne, in November 1992 (Glynn, 1992). 
4. An evaluation of those characteristics of Taha Maori programmes in Otago and Southland schools that are indicative of success. The results of this project were also presented at the joint AARE/NZARE conference in November of 1992 (Holmes, 1992).

5. An investigation of iwi-preferred school strategies and practices in Maori Education in Otago. The hui for this consultation are currently underway.

6. Te Huarahi Trust's Whanau literacy and numeracy project. This project is to record and research the development of a Maori PTE (Private Training Enterprise) using a participant driven empowering methodological framework.

7. Development of research skills among students. To this end the Student Practicums for courses Maori Studies 204 and Education 320 are conducted within the kaupapa of the research group. A monograph of examples of student research was produced in 1992 (Bishop, Bradley and Tokona, 1992b) and a preliminary report was made to the joint AARE/NZARE conference in November, 1992 (Bishop \& Kapa, 1992).

\section{Suggestions for Future Research}

Suggestions by the Ministry of Education on the basis of the Hirsch (1990) report include:

- the need to consider teaching styles more appropriate for Maori learners;

- the needs of pre-school children graduating from Te Kohanga Reo;

- the effectiveness of Taha Maori programmes in mainstream education;

- the impact of Kura Kaupapa Maori on the life chances of Maori children;

Other areas that have been suggested include:

- development of policies and practices to promote home and school relationships;
216 Russell Bishop

- establishment of a Kura Kaupapa Maori in Otago: feasibility and history;

- life histories projects;

- what languages are being taught, by whom, and to what level?;

- text books: what is being taught, what messages are being passed;

- Mana Whenua? Mata Waka? How are schools addressing these issues?;

- Teaching and learning styles as they reflect the achievement of Maori children;

- What exactly is an "appropriate learning environment"?;

- Assessment needs and issues;

- How are Boards of Trustees implementing Treaty and equity goals of charters?;

- Taha Maori, what does it mean? How can it be defined biculturally? What is it really meant to do? Is it meant to awaken Pakeha New Zealanders to the validity of Maori culture and language? Is it to enhance the identity and self worth of Maori pupils and how may it enhance their educational achievement? What are some successful methods of implementation, and what has been the fate of some innovations like Te Kete Raukura?;

- Can racism be recognised, identified and educationally expunged from Aotearoa/N.Z?

Following consultation with interested parties in Otago and Southland some further areas for research that are crucial for this region have been identified. These are:

\section{Te Reo}

There have been and there continue to be strong advocacy and compelling arguments for bilingual education in New Zealand. The Treaty guarantees the protection of this taonga of the Maori people. Maori is an official language in this country, and the UNESCO Convention against Discrimination in Education, Article 5, paragraph 1(c), states the need to recognise the right of members of national 
minorities "to the use or the teaching of their own language" (Hirsch, 1990 , p. 45). Language is the key to the culture. Language is also seen as the key to combating monoculturalism and assimilation/integration policies that are formalised institutional racism and to promoting social justice and human rights. Language is fundamental to democracy in our society. It is argued that language is the key route to enhancing Maori achievement, for "the language is not only the means of communication, but transmits within it the values and beliefs of a people" (Pere, 1988, p. 12).

Hirsch (1990) indicates eleven factors that necessitate the revitalisation of the language:

- the enhancement of identity;

- the intrinsic cultural value;

- the anthropological uniqueness;

- the relationship to the land

- the hope that bilingualism may lead to biculturalism;

- the enhancement of the cognitive domain;

- the enhancement of learning;

- the international dimension;

- vocational reasons.

- personal satisfaction;

- the Treaty of Waitangi.

Just how bilingual can schools become? What can realistically be expected? Are the answers already known by those following an alternative route? What hope is there for Maori children in state schools? Research is needed into the resource implications of establishing bilingual education, e g., what resources, training, back-up are actually necessary for successful implementation of bilingual education in New Zealand? How does this match the call for excellence in achievement?

What are the policy and resource implications for a strategy of language revitalisation within a school, within a city, within a region? What is existing? An intervention project could be established that consists of developing a well funded resource enterprise that would delineate the criteria that are necessary for success rather than the present situation where well meaning teachers and kaiawhina are extended beyond what can be reasonably expected. The danger of Maori continuing with these overstretched and under-resourced developments is that failure is possible because of over-committed people and an inadequately tested hypothesis. Maori people are very familiar with this failure syndrome and they must be vocal in resisting its perpetuation.

\section{Sanitisation of history}

Many Otago University students who take Maori Studies 204, Te Ao Hurihuri, which focuses upon the Treaty of Waitangi, the violations against the Treaty and the subsequent hegemonic sanitisation of history, express their dismay at the difference in perspective that a bicultural view can bring to a study of New Zealand history compared to the version they received during their own schooling.

Further research is needed into the impact of the sanitised history presented to our children and ourselves over the last century and particularly into the impact on children's ethnic self image. The education system founded in the 1870s in New Zealand was not founded upon notions of partnership as in the Treaty, it was founded upon racist ideologies that saw Maori as being inherently inferior to Europeans (Simon, 1990). This idea manifested itself into a duality that is still common to our national perception today. Two crucial ideas can be traced through to today, initially from the missionaries then reinforced by the settlers: that Maori people and their institutions were unable to cope with the changing world that culture contact brought, and that the alternative offered by the Europeans was inherently superior to that offered by indigenous peoples. These assumptions need identification and eradication.

\section{Evaluating peer influences}

Is there any substance to the claim that the peer group applies negative pressure to those who are succeeding within the system. Mitchell (1988, in Hirsch, 1990) claims this to be so in the case of secondary school mathematics. If this is the case, what intervention strategies/policies are necessary to intervene in the process? However, it could be argued that concerning ourselves about such a situation is another example of crisis research where the victim is further blamed for being unable to penetrate the racism of the institutions. It might be more appropriate to hypothesise that the dependence that many Maori students appear to have on the approval and acceptance of their peer group can be positive and not entirely negative. 


\section{Suspensions and expulsions}

What is the reality about suspensions and expulsions in Otago/ Southland? Is it the same pattern as for the rest of the country? What are the real causes?

Application of the model developed by the Race Relations Office (Hirsch, 1990) could be a useful procedure to identify the interaction between structural and individual causes. Intervention strategies that grow from this area could include examination and development of culturally appropriate guidance systems which would include evaluation of training programmes, timing of the intervention by counsellors, involvement of whanau/parents, and the overall kaupapa of the school.

\section{Retention rates}

McDonald (1988) shows that holding Maori boys back (up to 30\%)in the primers contributed to their leaving school early without qualifications when they reached secondary age. The flow on from this well -meaning action was that by 15 years of age, this cohort was still one year from school cert, had negative self image and negative attitudes to school.

According to Hirsch (1990) provisional figures for 1989 indicate that retention rates for non-Maori are improving faster than for Maori over the period 1982 to 1989.

Longitudinal studies are needed into the long term effects of programmes and the quality of courses in which Maori pupils are being retained. Are they transition to non-existing work or are they English, Maths and Science classes; i.e., are they the pathway to the working class or unemployment or to tertiary educational possibilities. Retention is important to improving life chances for Maori pupils. Levett, Lankshear, Jones and Braithwaite (1989) and Peters and Marshall (1989) indicate how schools can improve retention rates. Research using the models for reform proposed by these studies would be useful, especially indicating how policy, planning and review can facilitate change in these patterns.

\section{Parent/community involvement strategies}

Reforms in education must address the need to gain the confidence and involve parents and community members in the process of schooling. With the initiatives of Tomorrow's Schools and the Education Act 1989, what evidence is there of schools reaching out and involving their communities in the everyday life of their institution? What evidence is there of innovative programmes in schools to address parental hesitation?

\section{Affirmative action}

Research is needed into (a) the effects of affirmative action policies; (b) the whole area covered by E.E.O.; (c) the impact of these policies on the enhancement of life chances of Maori people; and (d) control of Maori over the research and education establishment.

\section{Conclusion}

Given the concerns that Maori people are voicing over the role and impact of research into their lives it is necessary for educational researchers to question the purpose of their research. In doing this they will need to question the research paradigm and the methodological framework of each research project. Te Ropu Rangahau Tikanga Rua has been established within the Education Department of the University of Otago to promote this critique and a Maori preferred methodological framework for educational research. Currently there are five major projects and a series of student practicums working within this kaupapa. There is an enormous range of educational research needing to be done to promote the life chances of Maori children and Maori people as a whole. The emphasis must be on a re-evaluation of methodological paradigms to cater for ethnic diversity, within a research kaupapa that is Maori controlled.

\section{Appendix}

The Organisational Structure of the Bicultural Research Group: Te Ropu Rangahau Tikanga Rua Education Department, Box 56 Dunedin.

Pou Here Tagata:

Huata Holmes, Kai Tahu, Kati Mamoe, Waitaha. Principal, High Street School. Research Affiliate, Education Dept., University of Otago, 1992.

Kaiwhakahaere: Russell Bishop, Waikato. Education Dept., University of Otago. Prof. Ted Glynn, Education Dept., University of Otago. 
Research Coordinator: Jane Bradley, Education Dept., University of Otago.

\section{Research Project Organisers:}

$\begin{array}{ll}\text { 1. Huata Holmes } & \text { Research Affiliate, Education Dept., } \\ \text { University of Otago. }\end{array}$

2. Russell Bishop Lecturer in Bi-cultural Education, Education Dept., University of Otago.

3. Ted Glynn Professor, Education Dept., University of Otago.

4. Jane Bradley Research Assistant, Education Dept., University of Otago.

\section{Keith Ballard Associate Professor, Education Dept, University of Otago.}

6. Monty Montgomery Resource Teacher of Maori, Otago Region.

7. Marie Joyce Resource Teacher of Maori, Otago Region.

8. Alva Kapa Kai Tahu, Lecturer, Southern Campus, Dunedin College of Education

\section{Notes}

1. Acknowledgements: I am grateful to Jane Bradley, Ted Glynn, Alva Kapa, Keith Ballard and Monty Montgomery for their ideas and help during the preparation of this paper.

2. Literally a dispersal.

3. These were the decades immediately after the signing of the Treaty of Waitangi when the struggle for sovereignty was at its height.

\section{References}

Bishop, R. "Te ropu rangahau tikanga rua: The need for emancipatory research under the control of Maori people for the betterment of Maori people." A paper presented to 13th NZARE Conference. Knox College, Dunedin,1991a.

Bishop, R. He whakawhanaungatanga tikanga rua: Establishing family links: A bicultural experience. Unpublished MA thesis. Department of Education, University of Otago, 1991b.
222 Russell Bishop

Bishop, R. "Ko te whakawhanaunga tikanga rua: Rediscovery of a bicultural family: Some methodological and ethical implications." A paper presented to the 13th Annual NZARE Conference. Knox College, Dunedin, 1991c.

Bishop, R. "Towards a paradigm for participant driven empowering research." A paper delivered to the Summer Workshop for the Development of Intercultural Coursework at Colleges and Universities. Institute of Culture and Communication, East-West Centre, Honolulu, Hawaii, 1992a.

Bishop, R."The establishment of a bicultural research group within the Education Department of the University of Otago." A paper submitted to the Otago Maori Council. Te Ropu Rangahau Tikanga Rua, Department of Education, University of Otago, 1992b.

Bishop, R., Bradley, J., \& Tokona, R. (eds) An evaluation of te huarahi mo te katoa hui: 9-11 August, 1991. Dunedin. Te Ropu Rangahau Tikanga Rua, Department of Education, University of Otago,1992a.

Bishop, R., Bradley, J., \& Tokona, R. (eds) Rangahau Taira: Examples of Student Research. Monograph No. 2, Te Ropu Rangahau Tikanga Rua. Department of Education, University of Otago, 1992b.

Bishop, R., \& Kapa, A. "Student practicum as participant driven empowering research: A preliminary investigation." A paper presented to the 14th NZARE. Conference. Geelong, Australia, 1992.

Bishop, R., and Glynn, E. "He kanohi kitea: Conducting and evaluating educational research." NZJES, 27, 2, pp. 3-13, 1992.

Carr, W., \& Kemmis, S. Becoming critical. London: The Falmer Press, 1986.

Curtis, T. "A Maori viewpoint related in research in Maori education." Discussion Paper, Auckland College of Education, 1983.

Giroux, H. A. Theory and resistance in education: A pedagogy for the opposition. Massachusetts: Bergin and Garvey Publishers, Inc., 1983.

Glynn, T. "From pause, prompt, praise to tatari, tautoko, tauawhi: A bicultural process of adaptation." A paper presented to the 14th NZARE Conference. Geelong, Australia,1992.

Hirsch, W. A report on issues and factors relating to Maori achievement in the education system. Auckland: Ministry of Education,1990.

Holmes, H. "Tu mai tu atu: Taha Maori in Otago and Southland schools." A paper presented to the 14th NZARE Conference. Geelong, Australia,1992.

Jones, A., McCulloch, G., Marshall, J., Hingangaroa Smith, G. and Tuhiwai Smith, L. Myths and realities. Palmerston North, The Dunmore Press Ltd, 1990.

King, M. Te ao hurihuri. Auckland: Hicks Smiths, 1976. 
Levett, A., Lankshear, C., Jones, A., Braithwaite, E. Keeping them at school at Henderson High. Auckland: Department of Education, 1989.

Livingstone, D. W. Cultural pedagogy and cultural power. Introduction by P. Freireand H. Giroux. Massachusetts: Bergin and Garvey Publishers, 1987.

McDonald, G. Promotion, retention and acceleration: How the school promotion structure produces inequalities in the face of good intentions. NZCER, set item 3, (2), 1988.

Ohia, M. Research for Maori Education. Address to NZARE Conference, Trentham. Proceedings of the conference, 1989.

Peters, M., \& Marshall, J. Issues concerning the schooling and retention of Maori secondary students in Tai Tokerau (Northland). Wellington: Department of Education, 1989.

Pere, R. Te Wheke: Whaia te maramatanga me te aroha. In Middleton, S. (ed) Women and education in New Zealand. Wellington: Allen and Unwin, 1988, pp. 6-19.

Simon, J. A. The Role of Schooling in Maori-Pakeha Relations. Unpublished PhD Thesis. Auckland University, 1990.

Smith, G. H. Taha Maori: Pakeha capture. In J. Codd, R. Harker and R. Nash (eds), Political Issues in New Zealand Education (pp. 183-197). Palmerston North: Dunmore Press Limited, 1990.

Smith, L.T. Te rapuna i te ao marama: Maori perspectives on research in education. In Morss J. R. and Linzey, T. J. (eds) The Politics of Human Learning: Human Development and Educational Research (pp. 46-55). Dunedin: University of Otago Press, 1991.

Stokes, E. Maori research and development: Discussion paper, Social Sciences Research Committee of National Research and Advisory Council, 1985.

Stokes, E. "Maori geography or geography of Maoris" in New Zealand Geographer, 4 (3), 1987, pp. 118-123.

Walker, R. "A consumer view of research" in New Zealand Journal of Educational Studies, 14, 1979, pp. 91-93.

Walker, R. Ka whawhai tonu matou: Struggle without end. Auckland: Penguin, 1990.

\section{The author}

Russell Bishop is a Lecturer in bicultural education in the Education Department of Otago University. His previous experience includes teaching at high schools and teacher training. He is currently undertaking a PhD study into the process of conducting participant driven research for the empowerment of Maori peoples. 